\title{
TRANSLATION PROCEDURES OF MISSION IMPOSSIBLE: ROGUE NATION MOVIE SUBTITLE
}

\author{
Cicih Nuraeni \\ cicih@bsi.ac.id \\ Mohamad Aditya Pratama \\ adityabeyonce@gmail.com \\ Universitas Bina Sarana Informatika Jakarta
}

\begin{abstract}
The objective of this research is describing on translation procedures which used for the government and covert institution terms in Mission Impossible: Rogue Nation movie subtitle by the official subscene translator. Translation procedures are the inseparable aspects within translation process which determine their end-result delivered for target reader rightly. The researchers applied Newmark's theory for subtitle analysis. By the process of analysis, it was found that there were 16 of 18 types of translation procedures which could be categorized into two specifications. The frequently procedures found were literal translation, transference, modulation, and shift or tranposition. In addition, the relevant procedures of specific terms were cultural equivalence, functional equivalence, through translation, and paraphrase.
\end{abstract}

Keywords: translation procedures, Newmark's theory, movie, subtitle

\section{INTRODUCTION}

Translation can be defined as the course of action or as the product of its result which emphasizes the message delivering from one language to another. In other words, the rendering process of a meaning is focused on the lexical, grammatical orders, communication contexts, and cultural aspects from the source language into the target language designated as a translation (Riyanto 2016). By that action, translator as a doer has to consider of several aspects, namely diction, cohesion, coherence, and cultural background, in order to afford understanding.

In this decade, translation is applied for one of knowledge sources, ability acquisitions, and assessments, either in education system or showbizz industry. The inclusion of methodologies and techniques related to the field of translation, the adaptation of the language and activities in ESP course include the grammar, lexis, register and skills specific to such field (Liendo 2015).
English for Specific Purposes as the language approaches in translation major is specifically oriented to the lexical and structural adjustment. The use of translation as a pedagogical tool is absolutely beneficial to develop ESP learners' comprehension skills (Rushwan 2017). Translation assists the learners to the mastery and comprehension of English abilities appropriately. It has a good effect to the pedagogical system.

Translation is neither ineffective nor inaccurate tools any longer as a learning process in foreign language classes. It is valued as the means of enriching and drilling for English competences, such as reading, writing, vocabulary building, speaking, and grammatical structure (Emzir 2015). Those acquisitions are utilized to increase the learners' capabilities of interaction between two different languages accurately. ESP translation course is directed to enlarge the linguistics competence for the advanced levels. 
Translation is often viewed as the inherent fifth skill alongside the other four skills. Translation facilitates cultural understanding, communication of ESP learners, improves the knowledge of a specific field and skill which focusses on accuracy in the contexts and future professional settings (Mažeikienè 2018).

Translation studies play its roles not only to transfer what the translated-text of one language into another language for having the similarity of meaning and context, but also it happens verbally while the spoken form is uttered and then transmuted into the written text as a translation. It definitely changed the world's perspectives concerning about translation, as the process as well as the product. It is proven by the increased translation product on showbizz industry lately. It appears in written texts as a product ordinarily. Hence it becomes unconventional whereas the translated-text shown on the screen as the updated-product named subtitle.

Subtitle as a new translation major is stressed on changing the verbal form into written-texts shown on the screen. By the process, the translator should pay attention to the essential translation aspects, especially translation procedures.

This research aimed at looking for the relevant procedures of specific terms and their types which are used in Mission Impossible: Rogue Nation movie subtitle. Translation procedures are stressed on the linguistics competences. One of them is a prior knowledge (Putra 2017) which is intended to afford the applicable subtitle for target reader's sense. By that concern, translator applies a number of competences to gain similar impressions, meaning, and value from SL into TL (Puspani \& Ni Luh 2018).

Based on the introduction above, this research is focused on subtitling procedures in filmic media which are displayed below the image (Cintas \& Anderman 2009; Gottlieb 2001). It proposed to analyze and find out of translation procedures in Mission Impossible: Rogue Nation movie subtitle which were stressed on its specific watchwords for the government institution.

\section{LITERARY REVIEW}

Amri (2017) has conducted an analysis on subtitling translation of Django Unchained movie from English to Indonesian focusing on its equivalences, in order that the meaning in SL could be delivered and understood in TL suitably. The translator acqusitions were able to disclose the equivalence, so that the target readers could realize the outcomes. Translation procedures proficencies wereused by translator to achieve for the respectable and apprehensible translation. It inferred that there were conformities of subtitling translation, for instance the SL and TL correlations, translator's ability of expressing the SL and TL correlations, mastering for the availabled translation strategies. Those elements aimed at yielding a translation comprehensibility for target reader sense.

Supardi \& Putri (2018) analyzed the audiovisual translation, that is subtitling and dubbing of Frozen: Let It Go movie soundtrack. The translator had to follow the subtitles with precise translation. This included removing, adding, and altering the structures of the text in TL in order to gain a good translation quality in film translation. Subtitling translation required a particular etiquette, due to the differences in translation treatment between texts and texts, and between spoken forms into texts. It often involved converting or expansion in TL's source to produce a movie subtitle translation perfectly. 
Those two analyses above concern on movie subtitle equivalences and techniques. There are no further explanations of translation procedures and techniques in movie subtitles as a part of translation aspects instead. It would result in different analysis while the other experts recognized them as the procedures.

By that reason, here the researchers concentrated on analyzing translation procedures of Mission Impossible: Rogue Nation movie subtitle. The researchers condensed another translation issues, particularly the types of translation procedures generally found in this movie subtitle and the relevant procedures for specific terms.

\section{UNDERLYING THEORIES Translation}

Translation is an operation performed on languages: a process of subtituting a text in one language for a text in another (Catford 1965). It implies that the process of meaning diversion from SL into TL by revealing its original source text of SL into TL equivalence for target reader sense. It is supported by Larson (1984) who states that translation consists of changing from one state or form to another, to turn into one's own or another's language change of form. The reconstructing activity of meaning or form in source language into target language entirely embodies word, phrase, clause or sentences.

Another linguistic expert explained that translation is a craft consisting in the attempt to replace a written message and or statement in one language by the same message and or statement in another language (Newmark 2001). The remodeling instrument of a written-text from source language into target language, both in its meaning and affirmation, is intentionally defined as a translation.

Hatim \& Munday (2004) defines translation into several notions as follow:
1. The process of transferring a written text from SL to TL, conducted by a translator, or translators, in a specific sociocultural context.

2. The written product, or TT, which results from that process and which functions in the socio-cultural context of the TL.

3. The cognitive, linguistic, visual, cultural and ideological phenomena which are an integral part of 1 and 2 .

By that process, it is stipulated in a matter of language norms which result in the product called a translation. It occurs between two different languages; the source language (SL) and the target language (TL). It consists of verbal or written forms between SL and TL.

The researchers inferred from the four expert theories above about the mechanism of parsing and reproducing a meaning in source language into target language and by the process, the translator as the main doer outcomes his/her product: a translation. In translating, the translator does not only alter a material text in SL into TL, but also pays attention to the elements adhering to the texts of SL the to target readers' senses appropriately.

\section{Translation Process}

As denoted by (Newmark 1988) the process of translating procedure is operational. Firstly, by choosing a method of approach and then focusing on the four levels as follow:

1. The SL text level, the level of language, where it begins and which it continually (but not continuously) go back to;

2. The referential level, the level of objects and events, real or imaginary, which it progressively have to visualize and build up, and which is an essential part, first of the comprehension, then of the reproduction process; 
3. The cohesive level, which is more general, and grammatical, which traces the train of thought, the feeling tone (positive or negative) and the various presuppositions of the SL text. This level encompasses both comprehension and reproduction: it presents an overall picture, to which it may have to sentences or expressions referring to the cultural categories, objective materials, substances and phenomena in TL. Those Newmark's translation levels above also confirmed by another expert concisely.

The meaning transferred and must be held constant. Translation then consists of studying the lexicon,

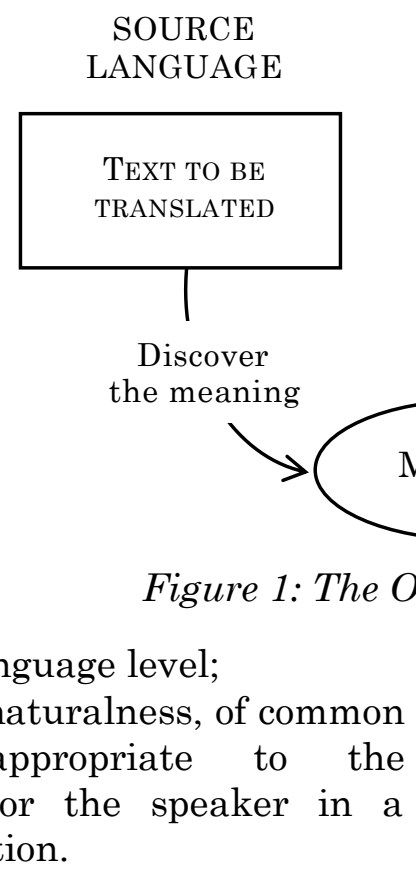

A (SOURCE LANGUAGE)

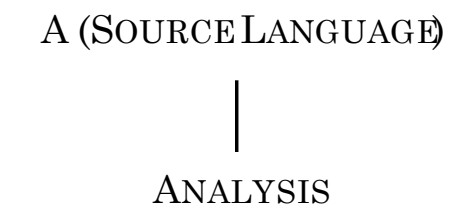

$\downarrow$<smiles>C1CC1</smiles>

4. The level of naturalness, of common language appropriate to the researchers or the speaker in a certain situation.

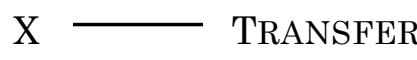

\section{Figure 2: The Process of Translation}

The acquisitions above, the mastery of lexicals, grammatical structures, communication contexts, and cultural elements have to be possessed by the translators, in order that their translation could be conveyed to the target readers' senses properly. It is necessary for the translator to comprehend the meaning in SL as well as shape and adjust dictions into grammatical structure, communication situation, and cultural context of source language text. Analyzing it in order to determine its meaning and reconstructing this same meaning using the lexicon and grammatical

\section{B (RECEPTOR LANGUAGE)}

\section{RESTRUCTURING}

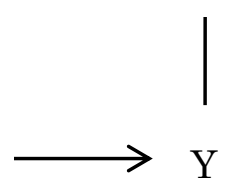


and the consideration of grammatical structure, as well as the communication situation and cultural conditions from SL into TL.

Later, Hatim \& Munday (2004) give details to Nida \& Taber's model that there are three phases in the process of translation as follow:

1. Analyzing the SL message into its simplest and structurally clearest forms (or the kernels')

2. Transferring the message at this kernel level

3. Restructuring the message in TL to the level which is most appropriate for the audience addressed.

The three stages of Nida's model above could be shown in Figure 2 by (Munday 2008).

The process of translating figure above splits into three types, i.e: analyzing, transferring, and restructuring. Analyzing deals with the translator's understanding of SL meaning intelligibly. In this beginning process, the translator demands on having the linguistics competence and prior knowledge. Those are the situation contexts and cultural aspects, both in SL and TL.

Transferring focuses on the SL text replacing by TL's equivalent norms or target readers' senses properly and correctly, in order that the output in TL meaning is exactly the same as in SL meaning.

The last processes, restructuring functions to result a translation as a natural, adapted, and balanced product. It notices target language or target readers' senses so that the result becomes as exactly as the original works within same atmosphere, so that it is clearly away from clumsiness.

The researchers sum up that process is a necessity in translating, especially for translator as a doer. Translators are insisted on having capabilities to comprehend and state the materials both in SL and TL form. Those are solemnly to simplify conveying a material from SL to TL and procreate a translation relevantly.

\section{Translation Procedures}

Translation procedures often appear in other terms, such as 'translation strategies' or 'translation techniques'. Those terms have the same functions and purposes for assisting the translator to render the object materials from SL into TL. There are inseparable components within the translation process which focuses on linguistics competences. It begins by implementing one of the translation procedures named restructuring. Those procedures are stressed to achieve acceptable translation as a product, commonly known as techniques ((Putra 2017). It is proposed to convey a meaning or form from SL to TL and then to produce a target language output close to target readers' senses.

Additionally, Said (2016) expresses those aspects as translation strategies. It is applied for finding an SL message and then obtaining TL equivalence. There are different cultural comprehension and lexical inconsistencies between two languages, such as phrases or idioms intricating to deliver, so that is why adaptations are sometimes applied a word-for-word equivalence for translation strategies. These priorities completely assist the translator to make a good translation for the target reader.

While translation methods relate to whole texts, translation procedures are used for sentences and the smaller units of language as pointed by Newmark (1988). It is used for stressing on each word of the sentences to decipher a material text in SL into TL. Meanwhile, the methods are used for translating a text thoroughly. Those points are functioned to reduce the translation impediments from SL into TL

There are eighteen types of translation procedures according to Newmark (1988) as tehe followings: 
1. Literal translation

Literal translation transfers SL grammar and word order, as well as the primary meanings of all the SL words into TL words. the rendering of SL into TL precisely. SL translated according to grammatical functions into TL oriented suitably. (Example: SL: somebody $\rightarrow$ TL: seseorang).

2. Transference

Transference is the process of transferring a SL word to a TL text as a translation procedure. This procedure occurs from SL into TL referring to its contexts and forms transfered. (regular $\rightarrow$ reguler)

3. Naturalization

Naturaization adapts the SL word first to the normal pronunciation, then to the normal morphology of the TL. It is used in TL by adapting the original phonetics and morphemes in SL. (performance $\rightarrow$ performanz)

4. Cultural equivalence

Cultural equivalence is an approximate translation where an SL cultural word is translated by a TL cultural word. It is translated by potraying of SL specifically the same as in TL cultural terms. (cocka-doodle-do $\rightarrow$ cocorico)

5. Functional equivalence

Functional equivalence requires the use of a culture-free word, sometimes with a new specific term. It, therefore, neutralizes or generalizes the SL word. An unknown term in SL can be conveyed through culture-neutral word in TL by stating its equivalence meaning. (licensed card $\rightarrow$ SIM)

6. Descriptive equivalence

Descriptive equivalence is an essential element in explanation. Its function is used to be neglected. It describes through the specifications and or characteristics of the object by supporting the detailed descriptions in TL. (tukang panjat kelapa $\rightarrow$ The men climbing the tree)

7. Through translation

Through translation is a kind of literal translation of common collocations, names of organizations, as well as the components of compounds and phrases. It renders for specific terms in SL by borrowing another expressions into TL literally. (CIA $\rightarrow$ Badan Intelijen Pusat)

8. Synonymy

In the sense of a near TL equivalent to an SL word in a context, where a precise equivalent may or may not exist synonymy is applicable. This procedure is used for an SL word with no clear one-to-one equivalent. It changes $\mathrm{s}$ word into different shapes. Hence its meaning and form in TL is exactly as equal as the one in SL. (kind person $\rightarrow$ personne Gentile)

9. Shift/transposition

Shift/transposition involvea a change from singular to plural. The grammatical structure does not exist in the TL. literal translation is grammatically possible but may not accord with natural usage in the TL and the replacement of a virtual lexical gap. The change from SL into TL is related to class words, units, and formats without transmuting its meaning. (a pair of glasses $\rightarrow$ sebuah kacamata)

10. Modulation

Modulation is a variation through the change of viewpoint or perspective and very often of category of thought either lexically or structurally from SL to TL. (never stop to do $\rightarrow$ terus melanjutkan)

11. Recognized translation

Recognized translation is used for official or generally accepted translation of any institutional terms. It is restricted to authoritative names. (constitutional state $\rightarrow$ rechtsstaat) 
12. Translation label

Translation label is a provisional translation (new institutional terms) which should be made in inverted commas. This is almost the same as recognized translation which emphasizes conditional names. (heritage language $\rightarrow$ langue d'heritage) written texts. This happens by condensing SL information into TL information. (children of the chamber $\rightarrow$ tamu dalam pernikahan)

17. Paraphrase

Paraphrase is an amplification or explanation of the meaning of a segment of the text. It is used in an

Table 1: The Instrument of Analysis

\begin{tabular}{clccc}
\hline \multirow{2}{*}{ No } & Translation & \multicolumn{2}{c}{ Movie Subtitle Data } & Translation \\
& \multicolumn{1}{c}{ Issues } & SL & TL & Procedures \\
\hline \multirow{2}{*}{1} & General and & Utterance & Subtitle & Procedure \\
& Dominant Types & Utterance & Subtitle & Procedure \\
\hline
\end{tabular}

13. Compensation

Compensation is used for overcoming loss of meaning, soundeffect, metaphor or pragmatic effect in one part of a sentence by compensating it in another part of or in a contiguous sentence when the elements in SL cannot not be replaced or there is no similarity in TL. (Me? $\rightarrow$ Apaan?)

14. Couplet, triplets, and quadruplets Couplet, triplets, and quadruplets combine two, three or four of the above-mentioned procedures respectively for dealing with a single problem. These procedures can be identified by the constitution of two or more different procedures (Hartono, 2018). (tooth and nail $\rightarrow$ Mati-matian)

15. Component analysis

Component analysis is splitting up a lexical unit into its sense components. The results can be from one to two, three or four translations. The units in SL are translated into certain detailedmeanings in TL.

(run $\rightarrow$ berlari, mengatur, mengelola, mengalir)

16. Reduction and expansion

Reductiona and expansiaon are used for imprecise translation procedures, particularly in poorly 'anonymous' text when it is poorly written or has important implications and omissions. Paraphrase can be applied by giving description and clarification in TL expression. (the central of trade $\rightarrow$ pusat semua jenis perdagangan)

18. Gloss, notes, and addition

In gloss, notes, and addition, the translator may have to add to his version that is normally cultural (between SL and TL culture)dealing with the topic or linguistic elements. There is optional information by adding more explanations in TL. (the kombinat $\rightarrow$ combine)

Those translation procedures above which are sometimes defined into nother terms are the appliances to cope with the translation impediments and to afford equivalence in target readers' senses. Translation methods are centered on the text entirely, whereas translation procedures are targeting to look for how the detailed-meaning in SL are translated into TL properly.

\section{Subtitling}

Subtitle is freshly invented and constitutes of a written texts as a product which showing in tune with picture on the screen. Subtitling connected to the audiovisual 
translation which spotlights spoken forms into written texts.

Subtitle translation is never confined to static frames or shots, but involved much larger filmic units, such as scenes, sequences, stages and even the whole text. The analysis of subtitle translation by highlighting the roles of both static and dynamic images in the subtitling process and involving the holistic analysis of audiovisual texts rather than mechanical combination of isolated stills (Chen \& Wang 2016: 84).

Subtitling is an advanced way for integrating the cultural categories between source text and target text in film translation. The mechanical difficulties of subtitling are being omitted, because it contains broad dynamic elements. Those are setting, starring stars, and written texts which are displayed on the screen for its purpose.

\section{RESEARCH METHODS}

This research used descriptive qualitative method. The term 'qualitative' refers to research that is based on descriptive data that does not make (regular) use of statistical procedures (Mackey \& Gass 2005, 162). It is stressed on regular data descriptions. It neither consists of figures and calculations of numbers nor belongs to statistics. The instrument of analysis of this research can be seen on Table 1.

\section{Source of Data}

The primary data source of this research is Mission Impossible: Rogue Nation movie which was downloaded from the official website of Dunia Layar Kaca; dunia.lk.21.com. Meanwhile, the English and Indonesian subtitle scripts were taken from https://subscene.com/subtitles/ mission-impossible5/indonesian/119377 8 and https://subscene.com/ subtitles/ mission-impossible-5/english/1216923. These subtitle scripts assisted the researchers for classifying the translation procedures. This movie genre is thriller action and it was released in 2015 with total duration 02:11:47.

\section{Data Collection}

The preparation to settle of data in this research were accomplished by watching Mission Impossible: Rogue Nation movie as well as reading, and comprehend both in English and Indonesian subtitle scripts for several times. After that, the researchers dentify and analyze the subtitles along with marking English and Indonesian subtitle scripts based on each utterances of the characters.

The researchers used library research in Results and Discussions section to find out and analyze the translation procedures in Mission Impossible: Rogue Nation movie subtitles by using English and Bahasa Indonesia lexicons from both online and conventional dictionaries.

The online English dictionaries were accessed from www.urban dictionary.com and www. cambridge dictionary.com whereas the Indonesian dictionary was retrieved from kbbi.kemdikbud.go.id. Meanwhile, the conventional dictionaries were provided by Indonesian-English Dictionary Third Edition (Echols \& Shadily 1994), English-Indonesian Dictionary Updated Edition First Edition (Echols \& Shadily 2014), Oxford Advanced Learner's Dictionary of Current English (Hornby 2000), and Dictionary of Idioms and Idiomatic Expression (Sullivan \& Hadi Podo 2003).

Other procedures in collecting the data were reading books and journal articles concerning translation studies.

\section{RESULTS AND Discussions}

The researchers used Newmark's theory for movie subtitle analysis. There are two translation issues in this research 
that is stating and analyzing translation procedures in Mission Impossible: Rogue Nation movie subtitles from English into Indonesian version.

1. The stating of translation procedures

It involved 1184 data from English into Indonesian subtitle version. The researchers found 16 types of translation procedures applied to this movie subtitle leaving descriptive equivalence and translation label (see Table 2).

2. The analyzing of translation procedures

The researchers obtained the data of translation procedures and analyzed of the whole issues into two categories as the following desciptions.

\section{The Types of Common}

\section{Translation Procedures and Set Up}

There were 16 out of 18 types of translation procedures in this movie subtitle, namely literal translation, transference, naturalization, cultural, functional equivalence, through translation, synonymy, shift, modulation, recognized, compensation, couplet, component analysis, reduction, paraphrase, and addition.

Aside from that, there were 4 of 16 types of translation procedures which are categorized into the customarily procedures. Those are 583 data of literal translation, 99 data of modulation, 85 data of transference and 83 data of shifting procedure.

\section{Literal translation}

There were 584 data indicated this procedure and the researchers provided the representatives of data analysis below.

Datum Number: 239/Timeline: 00:20:18,437-00:20:21,047

SL : I believe that the Syndicate is a figment of his imagination.
TL :Aku percaya kalau Syndicate adalah bagian dari imajinasinya.

The datum in SL 'figment of his imagination' was translated into bagian dari imajinasinya in TL literally. The translator completely rendered of the source in SL into TL based on its grammatical structures and functions. The phrase 'figment of his imagination' were not translated separately. According to EnglishIndonesian Dictionary (updated edition) 'figment of his imagination' is defined as a whole unit and can be translated into kilasan khalayan saya. That definition which lies in TL is going through with SL context properly both in meaning and structure.

\section{Transference}

There were 85 data belonging to this procedures and the following is the example.

489/00:50:15,813-00:50:19,292

SL : Ethan Hunt is in Vienna because you allow him escape in London.

TL : Ethan Hunt di Wina karena kau biarkan dia lolos di London.

In the datum above, ,the translation of 'Vienna'- the name of capital city of Austria-into Wina belongs to transference procedure. Translator used a loan word by transferring the word of 'Vienna' in SL into Wina in TL by some conversion of letters or phonemes. It occurred through the changing of first letter ' $\mathrm{V}$ ' in 'Vienna' into ' $\mathrm{W}$ ' in Wina.

\section{Naturalization}

There were 44 data categorized into naturalization procedure. The following is one of the example.

535/00:55:23,805-00:55:26,594

SL : He's former British intelligence. TL : Dia mantan intelijen Inggris.

In the datum above, it was obvious that the word 'intelligence' which is translated into intelijen precisely adapt 
the SL spelling to the acceptable pronunciation in TL. The adaptation of SL word 'intelligence' into intelijen did not transmute the meaning in TL.

Synonymy

There were 11 data shown as synonymy and the researchers provided two examples of data analyses as follow.

392/00:43:12,585-00:43:16,441

SL : You means those other 2 idiots? I can only assumed they were redundancies.

TL : Maksudmu 2 orang bodoh itu bodoh itu? Aku hanya anggap mereka pelengkap.

The datum above denotes that translator used synonym procedure for rendering the word 'redundancies' in SL into TL as pelengkap. EnglishIndonesia Dictionary updated edition demonstrates 'redudancy' as kelebihan and by that definition, the procedure can be included into synonymy. The translated-text kelebihan in TL corresponds to the context in SL. It is shown by the previous scene that there are two additional shooters besides Ilsa Faust.

845/01:28:45,176 -01:28:47,361

SL : Ethan Hunt is a gambler.

TL : Ethan Hunt seorang petaruh.

The datum above is uttered by Solomon Lane to Isla Faust who reassuring of Ethan's conviction as the fighter. The word in SL 'gambler' is rendered into petaruh in TL by the translator. Based on An EnglishIndonesia Lexicon updated edition 'gambler' is defined as pejudi and it is basically going through to the context in this movie. The translator reflected the word 'gambler' in SL as similar to petaruh in TL or implied it as a tough fighter, both in meaning and related to the situation.

\section{Shift/transposition}

There were 83 data describing this procedure. The researchers found that there were several shift types of 83 data, i.e: the changes in part of speech, the changes of intrasystem, and the changes of uni,. The changes can be illustrated as follow.

The changes of part of speech

The researchers found that there were changes from adjectives into nouns, known as class shift. The datum below is the example of change in part of speech.

242/00:20:26,758-00:20:33,155

SL : He will be called upon to answer for every wanton active mayhem he's responsible for.

TL :Dia akan dipanggil untuk menjawab setiap kecerobohan yang dia pertanggungjawabkan.

The phrase in SL 'wanton active mayhem' was translated into kecerobohan in TL. The phrase 'wanton active mayhem' is identified as epithet or adjective order. It is applied for describing the noun 'mayhem'. The phrase 'wanton active' functions as an adjective to explain 'mayhem' as the noun. It would be awkwardness as translation if that phrase is translated by word-for-word, 'wanton active mayhem' into aniaya aktif yang ceroboh. In order to obtain the appropriate meaning in TL which is suitable to the context in SL, the translator applied class shifting procedure by rendering the phrase in 'wanton active mayhem' into kecerobohan in TL. It denotes that the above-mentioned phrase in SL has undergone class shifting from adjective into noun.

The changes of intrasystem

Intrasystem shift can also be defined as the change from plural in SL into singular form in TL. The following is the example.

750/01:23:17,255-01:23:21,813

SL :There are no allies in state craft, Ilsa.Only common interest. 
$\begin{array}{ccc}\mathrm{TL}: \text { Tak ada sekutu } & \text { dalam } \\ \text { kepentingan negarawan. } & \text { Ilsa. } \\ \text { Hanya kepentingan bersama. } & \end{array}$

Translator applied intrasystem shift procedure for rendering the word 'allies' in SL into sekutu in TL. The word 'allies' is exactly in plural form, but translator translated it into singular form sekutu. The translator translated from plural to singular without any changes in the context, both in SL and TL. The purpose of this procedure is to reduce and minimize the ambiguity and redundancy. It would be awkward if 'allies' in SL is translated into sekutu-sekutu in TL.

The changes of unit

Unit shifts occur by the change of word into phrase, phrase into clause, and vica versa.

163/00:14:15,743-00:14:19,152

SL : They call you, the bone doctor. TL : Julukanmu, dokter tulang.

In the datum above, the SL sentence in 'They call you' was translated into Julukanmu in TL. Here a sentence turns into a word in the process of translation. Translator did not apply literal translation for the sentence 'They call you' as Mereka memanggil kamu, in order to sustain the audience understanding in TL precisely. The word 'you' in SL was turned into a bound morpheme -mu indicating possesive form that is attached into the main word julukan.

\section{Modulation}

There are two types of modulation; obligatory modulation and free modulation. There were 99 data representing these modulation types.

Obligatory modulation

Obligatory modulation is applicable when there is no equivalence from SL to TL the process of translation. It is applied by changing the perspective, viewpoint, or structure, such as from active into passive form. The change of structure is emphasized on the meaning both in SL and TL.
259/00:22:33,074 - 00:22:36,340

\section{SL :WORLD BANK DECLARES CRISIS \\ TL :BANK DUNIA DINYATAKAN KRISIS}

The SL sentence 'World Bank declares crisis' indicates an active form. It is then translated in TL as a passive voice into Bank Dunia Dinyatakan Krisis. Actually, 'World Bank Declared Crisis' could be translated literally into Bank Dunia Menyatakan Krisis, but the translator avoid that procedure in order to maintain the SL sense acceptable in TL.

Free modulation

This procedure occurs by the change of viewpoint in meaning without considering the linguistic aspect.

388/00:43:02,180 - 00:43:05,324

SL : I went through the motion, that's not the same thing.

TL: Aku hanya melukainya, itu bukan hal yang sama.

The phrase 'to go through the motion' is defined by EnglishIndonesian Dictionary (updated edition) into bertindak atau melakukan sesuatu secara mekanis atau tanpa ketulusan. This phrase could not be renderred separately by the reason that it is a whole unit. The translator rendered the SL phrase 'went through the motion' into hanya melukai in TL. The process shows that there is difference between in SL and TL form. Nonetheless, the meaning and the idea of the phrase sustains. The researchers stressed the meaning in TL hanya melukai as appropriate to EnglishIndonesian Dictionary version bertindak tanpa ketulusan. It can be seen in the previous scene that the Chancellor of Austria is actually assassinated by the car bomb, neither Ilsa Faust nor two other gunmen.

\section{Recognized translation}

There were 10 data potrayed this procedure as the following example. 
780/01:25:02,532-01:25:04,939

SL : The Prime of Minister of Great Britain.

\section{TL : Perdana menteri Inggris.}

In the datum above, the translator translated 'The Prime of Minister of Great Britain' in SL into Perdana Menteri Inggris in TL literally. The translation procedure indicates recognized translation since both phrases are official institutional terms.

\section{Compensation}

There were 22 data stated to this procedure. The following is the example.

235/00:20:05,006 - 00:20:09,824

SL : How come the CIA has never discovered any actual Intel regarding this Syndicate.

TL :Kenapa CIA tak pernah temukan Intel mana yang sebenarnya terkait Syndicate ini.

The translator did not substitute the expression 'How come' in SL literally by Bagaimana datang in TL but prefered using Kenapa. It would be preplexing if the translator parsed it into literal translation, so that to mantain the equivalence and appropriate idea from SL to TL, compensation procedure was applied to introduce a stylistic effect and maintain information elements from SL to TL.

\section{Other procedures}

The researchers provided couplet, triplet, and quadruplet as kinds of translation procedures. The following data are the examples of each.

\section{Couplet}

There were 76 data belonging to this procedure. It is an application of two translation procedures. The following is an example of a couplet consisting of cultural equivalence and transference.

1088/01:49:36,660-01:49:42,487

\section{SL : 2 pounds Semtex, 500,30 caliber ball bearings.}

\section{TL : 1 kg Semtex, 500,30 kaliber Ball Bearings.}

1. Cultural equivalence was used for rendering 'pounds' in SL into $\mathrm{kg}$ in TL. Pounds is described as a mass in object and used in several countries to measure the weight. Meanwhile, in Asia kg (kilogram) is commonly used for the mass measurement. $1 \mathrm{~kg}$ equals 2,205 pounds which is then converted into 2 pounds. The change from 'pounds' into $\mathrm{kg}$ definitely considers a cultural aspect in translation.

2. Transference procedure occurred in SL datum 'Semtex' which is maintained into Semtex in TL. Semtex is identical to bomb. Online Cambridge Dictionary describes Semtex as 'a brand name for a powerful explosive used especially to make illegal bombs by terrorists'. Therefore, the use of Semtex refers to the function rather than the brand.

Meanwhile, the translator did not change the SL forms 'caliber' and 'ball bearings' and only transfer it in TL as they are. However, the word 'caliber' in SL was modified into 'kaliber' in TL. Oxford Advanced Learners' Dictionary defines 'caliber' as 'the quality of something' or 'the width of the inside of a tube or gun.' The Online Urban Dictionary explains 'ball bearing' as originated from the term 'ballin' or 'bear ballin' which means 'extreme to the maximum' or similar to 'a motorbike sphere of the death'. However, the researchers comprehend " 2 pounds Semtex, 500, 30 caliber bear ballings" as a superpower bomb which may cause a big blast explosion.

Triplet

Triplet constitutes three different translation procedures in a single unit of translation. There were 9 data related to this procedure. The following 
is an example of a triplet consisting of modulation, transference, and shift.

1076/01:47:33,274-01:47:37,548

SL : If Lane gets his hands on that money, we're unleashing a terrorist superpower.

TL : Jika Lane dapatkan uangnya, kita melepaskan adidaya teroris.

1. Free modulation was applied to the phrase 'gets his hand on that money' in SL which was translated into 'dapatkan uangnya' in TL. The datum in SL could be rendered into TL as mendapatkan di tangannya uang tersebut literally. However, the translator did not change the context and meaning form SL into TL. The translated-text is exactly the same as the original.

2. Transference procedure was applied in the translation of 'terrorist' in SL into teroris in TL. The translator do that by naturalizing the original into TL form.

3. Shifting/transposition happened to SL 'superpower' which was translated into adidaya in TL. It is a sort of class shift, specifically a change of part of speech. The word in SL 'superpower' as noun is substituted by an adjective adidaya in TL.

Quadruplet

Quadruplet is indicated by the use of four different translation procedures in a single translation process. Within the movie subtitle, there are 3 data showing quadruplet. The following is an example of a quadruplet consisting of addition, reduction transference, and synonymy.

328/00:28:11,304-00:28:16,234

SL : Meanwhile I'll try and overlook that you're an international fugitive wanted by The CIA.

TL : Berarti sementara kubaikan fakta bahwa kau ini buronan internasional yang diburu CIA.

The datum consists of four translation procedures from SL to TL.

1. Addition berarti is found in TL since its original form does not exist in SL.

2. Reduction occurred in SL WORDS 'try' and 'and' which were omitted by the translator in TL. Those terms could actually be translated into 'coba' and 'dan' in TL.

3. Transference happened to SL 'international' which was transferred naturally into internasional in TL.

4. Synonymy applied to SL 'wanted' which was translated into 'diburu' in TL. 'Wanted' is basically defined as menginginkan according to English-Indonesian Dictionary (updated edition). The use of diburu in $\mathrm{TL}$ is going through to the context of this movie. It is delineated by the previous movie scene in which the Director of CIA, Hunley wanted Ethan Hunt to surrender by the reason of all chaoses.

\section{Component analysis}

The researchers found 22 data representing componential analysis procedure. The following is the example.

158/00:14:01,374- 00:14:03,701

SL : Why don't you take off the cuff.

TL :Kenapa kau tak lepaskan borgolnya.

The term 'take off' in SL was translated into lepaskan in TL. The translator used component analysis in the process of translation. The term in SL is a phrasal verb and the translator took the procedure to elaborate each component. Actually, the phrasal verb 'take off' has different meanings, i.e: 'make a great progress', 'reduce the price of an item', 'leave the ground (plane)', and 'remove'. The term 'take off above is appropriate to 'remove' since the meaning closely related to the context of this movie.

\section{Reduction}

There were 45 data indicating reduction. The example can be seen below. 
562/00:57:00,896-00:57:04,028

SL :Well, that's easy. We just impersonate the agent who stole the ledger in the first place.

TL : Itu mudah. Kita pakai saja topeng agen yang mencuri catatan kasnya.

There is an omission in the translation. The datum in SL obviously demonstrates prepositional phrase in the first place' comprising 'in' (preposition), 'the first place' (noun phrase) which was omitted by the translator in TL. It could actually be translated literally into di tempat semula or di tempat awal. Reduction procedure is needed to prevent or minimize the redudancy and expression clumsiness in the translated-text.

\section{Addition}

There were some data representing addition. The following is one of them.

\section{1/00:08:50,631-00:08:54,792}

SL : Pursue us, you'll be caught. Resist us, you'll be killed.

TL :Jika mengejar kami, kau akan ditangkap. Melawan kami, kau akan dibunuh.

In the datum above, the TL term Jika has no source in SL. Oxford Advanced Learner's Dictionary shows that the word jika is equivalent to 'if' in SL functions as a conjunction. It is parallel to KBBI which states jika or kalau as a connecting word similar to 'if' in English. The word jika above functions as a conjunction to sustain the context of the movie despite situated at the beginning of the sentence.

\section{The Relevant Translation}

\section{Procedures in Specific Terms}

There were 4 of 16 types translation procedures inside the movie subtitle which indicate this specification issues. Those types are presented below.

\section{Cultural equivalence}

There were 9 data representing this procedure. Equivalence in cultural term is translated by potraying SL specifically the same as in TL cultural terms which focuses on its characteristic and meaning.

1149/02:00:06,511 - 02:00:11,278

SL: Face to face.

TL: Empat mata.

The term in SL 'Face to face' was translated into Empat mata in TL. It will reduce the meaning literally from Wajah ke wajah. 'Face to face' is identified as an idiomatic expression. In order to obtain acceptable translation, the translator looked for the equivalence of SL in TL. 'Face to face' has the meaning '(by extension, idiomatic) a close encounter with a thing or situation' and it has acceptable terms in TL as berhadap-hadapan or empat mata. In particular, the translator rendered SL term by finding its equivalence and precise meaning in TL by considering it as an idiom.

\section{Functional equivalence}

The researchers found 7 data related to functional equivalence procedure. They can be exemplified as follow.

194/00:18:00,286-00:18:02,758

\section{SL : Bravo Echo One One. TL : Bravo Echo 1-1.}

In the datum above, 'Bravo Echo One One' was translated into Bravo Echo 1-1 by translator. Those words belong to an international institution terms which have the descriptions separately. The translator sustained the words in SL 'Bravo Echo One One' to the audience in TL properly by its function. It would be clumsy if the translator parsed 'Bravo Echo One One' into Bagus Gema Satu Satu. 'Bravo Echo One One' already has equivalent meaning, that is 'Bravo' as Bandung in Indonesian alphabet term, 'Echo' does not have any meaning, and One One as 1-1 (Satu Satu) stands for the numbers as an expression for making a phone call.

\section{Through translation}

Through translation is also known 
as calque procedure. The researchers found 32 data belonging to this procedure. The following is one example.
Badan Intelijen Pusat. 'The Central Intelligence Agency' is commonly abbreviated into CIA. Oxford Advanced Learner's Dictionary defines 'CIA' as

Table. 2. The Summary of Data Representatives

\begin{tabular}{|c|c|c|c|c|}
\hline \multirow{2}{*}{ Data } & \multicolumn{2}{|c|}{ Subtitle } & \multirow{2}{*}{ Type } & \multirow{2}{*}{$\begin{array}{l}\text { Translation } \\
\text { Procedures }\end{array}$} \\
\hline & Source Language & Target Language & & \\
\hline 1 & figment of imagination & bagian dari imajinasi & - & Literal translation \\
\hline 2 & Vienna & Wina & - & Transference \\
\hline 3 & intelligence & intelijen & - & Naturalization \\
\hline 4 & redudancy & pelengkap & - & \multirow{2}{*}{ Syonymy } \\
\hline 5 & gambler & petaruh & - & \\
\hline 6 & Wanton active mayhem & kecerobohan & Class shift & \multirow{3}{*}{ Shift/transposition } \\
\hline 7 & wllies & sekutu & Intrasystem & \\
\hline 8 & They call you & julukanmu & Unit shift & \\
\hline 9 & Declares & dinyatakan & Obligatory & \multirow[b]{2}{*}{ Modulation } \\
\hline 10 & $\begin{array}{l}\text { To be through the } \\
\text { motion }\end{array}$ & hanya melukai & Free & \\
\hline 11 & prime of minister & perdana menteri & - & Recognized translation \\
\hline 12 & how come & kenapa & - & Compensation \\
\hline 13 & pounds & $k g$ & Cultural & \multirow{2}{*}{ Couplet } \\
\hline 14 & Semtex, ball bearings & Semtex, ball bearings & Transference & \\
\hline 15 & get one's hand on & dapatkan & Free & \multirow{3}{*}{ Triplet } \\
\hline 16 & terrorist & teroris & Transference & \\
\hline 17 & superpower & adidaya & Class shift & \\
\hline 18 & - & berarti & Addition & \multirow{4}{*}{ Quadruplet } \\
\hline 19 & try & - & Reduction & \\
\hline 20 & international & internasional & Transference & \\
\hline 21 & wanted & diburu & Synonymy & \\
\hline 22 & take off & lepaskan & - & Component analysis \\
\hline 23 & in the first place & - & - & Reduction \\
\hline 24 & - & jika & - & Addition \\
\hline 25 & face to face & empat mata & - & Cultural equivalent \\
\hline 26 & bravo echo one one & bravo echo 1-1 & - & Functional equivalent \\
\hline 27 & CIA & Badan Intelijen Pusat & - & Through translation \\
\hline 28 & right as rain & Segar kembali & - & Paraphrase \\
\hline
\end{tabular}

100201:41:54,421-01:41:57,596

SL : And yet, here we have the Central Intelligence Agency Indicating otherwise.

TL : Namun, Badan Intelijen Pusat menunjukan sebaliknya.

The SL term 'Central Intelligence Agency' is generally translated into standing for 'Central Intelligence Agency' as well. It is a department of the US government which collects information about other countries, often secretly. The translation is also confirmed by English-Indonesian Lexicon (updated edition) which equalizes CIA to Badan Intelijen Pusat $A S$. 


\section{Paraphrase}

The researchers found as many as 18 data indicating paraphrase usage. The exampe can be seen below.

666/01:10:58,412-01:11:01,32

\section{$\mathrm{SL}$ : You'll be as right as rain.}

TL : Kau akan segar kembali.

The translator used paraphrase in translating 'as right as rain' into segar kembali. It would be ambiguous and hardly accepted when 'as right as rain' is translated into sesehat seperti hujan literally. The SL term 'as right as rain' is related to simile. That is why the translator elaborated it as whole translation. The simile 'as right as rain' could be understood as 'everything is perfectly fine' or 'all right'. Here, 'as right as the rain' which was translated into segar kembali implies that Ethan Hunt would be in good and healthy condition.

Translation procedures have an essential function to mantain the meaning and value both in SL and TL. From Table 2, it could be delineated according to Newmark's (1988) term of translation procedures that the limitation issues of subtitling translation above more concentrated on its translatability and equivalence delivery. It is proved through translated-text of specific institution watchwords in this research which stressed on target readers' senses precisely.

\section{CONCLUSION}

There are two main points concluded from this research on translation procedures in Mission Impossible: Rogue Nation movie subtitle.

1. As many as 16 types of translation procedures were found, i.e: literal translation, transference, naturalization, synonymy, cultural equivalence, functional equivalence, modulation, shifting/transposition, couplet, through translation, compensation, recognized tran- slation, component analysis, reduction, paraphrase, and addition. Aside from that, the translator also proposed two, three or four different translation procedures to overcome the problems in translation. Meanwhile, the translation procedures frequently used in the movie subtitle were literal translation, modulation, transference, and shifting.

2. Cultural equivalence, functional equivalence, through translation and paraphrase were categorized into appropriate institutional terms, since this movie related to an international government institution.

The researchers expected that this research result might be advantageous for the further research by providing more explanations toward translation studies. This research, in advanced, would assist the readers in comprehending the translation studies, especially translation procedures, which involve two different languages.

Lastly, it is suggested to those who want to analyze translation either as a process or product to comprehend and consider all aspects related to translation procedures within the scope of translation studies.

\section{REFERENCES}

Amri, N. 2017. "Kriteria dalam Penerjemahan Subtitle Film Django Unchained Dari Bahasa Inggris ke Bahasa Indonesia". Jurnal Kata, 1(1), 80-93. Retrieved from ejournal. kopertis10.or.id/index.php/kata/article/ view/1953

Catford, JC. 1965. A Linguistic Theory of Translation: An Essay in Applied Linguistics. London: Oxford University Press

Chen, Y \& W. Wang. 2016. "Relating Visual Images to Subtitle Translation in Finding Nemo: A Multi-Semiotic Interplay". The International of Journal for Translation \& Interpreting, 
8 (1): 69-85. <https://doi.org/10.12807/ ti.108 201.2016.a05>

Cintas, JD \& G. Anderman. 2009. Audiovisual Translation: Language Transfer on Screen. London: Palgrave Macmillan

Emzir, E. 2015. Teori dan Pengajaran Penerjemahan. Jakarta: Rajawali Pers.

Gottlieb, H. 2001. Texts, Translation and Subtitling: in Theory and in Denmark. Copenhagen: University of Copenhagen

Hartono, Rudi. 2018. Novel Translation (Tripartite Cycle Model-Based Approach). Retrieved from rudihartono inggris.blog.unnes.ac.id/e-book/

Hatim, Basil, \& Jeremy Munday. 2004. Translation: An Advanced Resource Book. London and New York: Routledge

Larson, ML. 1984. Meaning-Based Translation: A Guide to CrossLanguage Equivalence. New York: University Press of America.

Liendo, P. 2015. "English for Translation Purposes; Straddling the Challenge". Translation Journal, (January). Retrieved from https://translation journals.net/jannuary-2015/english-fortranslation-purposes-straddling-thechallenge.html

Mažeikiené, V. 2018. "Translation as a Method in Teaching ESP: An Inductive Thematic Analysis of Literature". The Journal of Teaching English For Specific And Academic Purposes, 6(3), 513-523.

https://doi.org/https://doi.org/10.22190/J TESAP1803513M

Munday, Jeremy. 2008. Introducing Translation Studies: Theories and Applications. New York: Routledge

Newmark, Peter. 1988. A Textbook of Translation. New York: Longman
Newmark, Peter. 2001. Approaches to Translation (SFL.E Press ed.). Retrieved from https://www.4shared. com/office/cgdITadZba/Approaches_to_t ranslation_Pet.html?cau2=0322\&ua=LI NUX

Nida, Eugene A \& Charles R. Taber. 1969. The Theory and Practice of Translation (Volume VII). Leiden: EJ Brill

Puspani, IAM \& Ni Luh Ketut Mas Indrawati. 2018. "Translation Procedures in Translating English Poem into Indonesian". International Journal of Applied Linguistics \& English Literature, 7 (6): 12-17. Retrieved from https://journals.aiac. org.au/index.php/IJALEL/article/view/4 $819 / 3646$

Putra, PP. 2017. Penerjemahan Bahasa Inggris-Indonesia (Teori dan Praktik). Yogyakarta: Pustaka Pelajar

Riyanto, Slamet. 2016. Panduan Praktis Teknik Penerjemahan Text Books. Yogyakarta: Pustaka Pelajar

Rushwan, IMH. 2017. The Role of Translation in Developing ESP Learners ' Reading Comprehension Skills: A Case Study of Medical Students at Njaran University-KSA. International Journal of Applied Linguistics \& English Literature, 6 (3): 243-253. <https://doi.org/10.7575/aiac. ijalel.v.6n.3p.243>

Said, M. 2016. Penerjemahan: Teori \& Praktik. Tangerang: Pustaka Mandiri

Supardi, M \& Putri, DA. 2018. "AudioVisual Translation: Subtitling and Dubbing Technique-Movie Soundtrack in Frozen: Let it Go". Buletin Al-Turas, XXIV(2), 381-398. Retrieved from journal.uinjkt.a.id/index.php/al-turats/ article/viewfile/8621/4968 
138 Leksema Vol 4 No 2 Juli-Desember 2019 